Research Article

\title{
Combining ability of summer-squash lines with different degrees of parthenocarpy and PRSV-W resistance
}

\author{
Douglas Willian Nogueira ${ }^{1}$, Wilson Roberto Maluf ${ }^{1,2}$, Antonia dos Reis Figueira ${ }^{3}$, \\ Gabriel Mascarenhas Maciel ${ }^{2}$, Luiz Antonio Augusto Gomes ${ }^{2}$ and Cesar Augusto Ticona Benavente ${ }^{1}$ \\ ${ }^{1}$ Universidade Federal de Lavras, Departamento de Biologia, Lavras, MG, Brazil. \\ ${ }^{2}$ Universidade Federal de Lavras, Departamento de Agricultura, Lavras, MG, Brazil. \\ ${ }^{3}$ Universidade Federal de Lavras, Departamento de Fitopatologia, Lavras, MG, Brazil.
}

\begin{abstract}
The aim was to assess heterosis in a set of 16 summer-squash hybrids, and evaluate the combining capacity of the respective parental lines, which differed as to the degree of parthenocarpy and resistance to PRSV-W (Papaya Ringspot Virus-Watermelon strain). The hybrids were obtained using a partial diallel cross design ( $4 \times 4)$. The lines of parental group I were 1 = ABX-037G-77-03-05-01-01-bulk, 2 = ABX-037G-77-03-05-03-10-bulk, 3 = ABX-037G77-03-05-01-04-bulk and 4 = ABX-037G-77-03-05-05-01-bulk, and of group II, 1' = ABX-037G-77-03-05-04-08-bulk, $2^{\prime}=$ ABX-037G-77-03-05-02-11-bulk, 3' = Clarice and 4' = Caserta. The 16 hybrids and eight parental lines were evaluated for PRSV-W resistance, parthenocarpic expression and yield in randomized complete-block designs, with three replications. Parthenocarpy and the resistance to PRSV-W were rated by means of a scale from 1 to 5 , where 1 $=$ non-parthenocarpic or high resistance to PRSV-W, and $5=$ parthenocarpic or high susceptibility to PRSV-W. Both additive and non-additive gene effects were important in the expression of parthenocarpy and resistance to PRSV-W. Whereas estimates of heterosis in parthenocarpy usually tended towards a higher degree, resistance to PRSV-W was towards higher susceptibility. At least one $F_{1}$ hybrid was identified with a satisfactory degree of parthenocarpy, resistance to PRSV-W and high fruit-yield.
\end{abstract}

Key words: Cucurbita pepo, heterosis, hybrids, potyvirus, papaya ringspot virus.

Received: February 11, 2011; Accepted: May 15, 2011.

\section{Introduction}

Commercial deployment of summer-squash (Cucurbita pepo L.) hybrids is increasing, due to the reported heterosis for yield-related traits (Firpo et al., 1998; López-Anido et al., 1998; Ahmed et al., 2003) and the possibility of combining parental resistance to various pathogens.

Papaya ringspot virus-watermelon strain (PRSV-W) is responsible for significant losses in summer squash, whose cultivars are usually highly susceptible to this virus. Although management procedures to avoid viral diseases have been proposed, genetic resistance is considered the most suitable method of control. Even though satisfactory levels of resistance have been found in squash species such as Cucurbita ecuadorensis, Cucurbita maxima, Cucurbita foetidissima and Cucurbita moschata, as yet, no original source of resistance has been found in C. pepo accesses (Provvidenti et al., 1978; Maluf et al., 1986).

Send correspondence to Douglas Willian Nogueira. Departamento de Biologia, Universidade Federal de Lavras, 37.200-000 Lavras, MG, Brazil. E-mail: douglagen@yahoo.com.br.
In 1998, a C. pepo summer-squash variety (Whitaker) resistant to zucchini yellow-mosaic, cucumber mosaic and papaya ringspot viruses, as well as powdery mildew (Robinson and Reiners, 1999), was released. Resistance to PRSV-W, as presented by 'Whitaker', is controlled by more than one gene locus (Menezes CB, Doctoral thesis, Universidade Federal de Lavras, 2003). Furthermore, 'Whitaker' revealed a high degree of parthenocarpic expression, also found to be controlled by a single locus, but with incomplete dominance of the allele controlling parthenocarpy (Menezes et al., 2005; Silva et al., 2009).

The development of summer-squash hybrids with both parthenocarpy and resistance to PRSV-W would be highly desirable in Brazil, as a means of both reducing current deployment of insecticide sprays for controlling viral diseases, and providing greater adaptability to pollinationdeficient environments, such as indoor (greenhouse) production or outdoor-production in large areas with a low population of pollinating insects.

In spite of its desirable attributes of virus resistance and parthenocarpic fruit-set, 'Whitaker' does, however, present certain negative fruit-features, especially the dark- 
green coloration, which is unacceptable on the Brazilian market. In Brazil, the most widely grown summer-squash cultivars are Caserta, or hybrids with Caserta-type fruit. Caserta, although having a medium light-green fruit with dark-green stripes (lighter than Whitaker), is extremely susceptible to PRSV-W.

The aims were to (a) develop summer-squash hybrids among lines with a high degree of parthenocarpy and PRSV-W resistance, derived from the Caserta $\mathrm{x}$ 'Whitaker' cross; (b) select competitive hybrids for the local market; (c) estimate heterosis in these hybrids and (4) assess the combining capacity of hybrid parental lines.

\section{Materials and Methods}

Two different trials were carried out at the Vegetable Research Station of HortiAgro Sementes Ltda., Ijaci, MG, Brazil, from February 12, 2006 through November 15, 2006. Parthenocarpy and yield-related traits were evaluated in an outdoor experiment and PRSV-W in a confined experiment within a plastic house. The same genotypes were evaluated in both experiments.

Genetic material comprised 24 genotypes of summer squash (C. pepo L.), consisting of 4 lines in group I (used as female parental lines), 4 in group II (male parental lines), and 16 experimental hybrids from crosses between the two groups. The hybrids were obtained by using a partial diallel cross design $(4 \times 4)$ (Table 1$)$.

All the ABX-037G lines, originating from 'Caserta' $x$ 'Whitaker' crossings, were selected for PRSV-W resistance, parthenocarpy and fruit characteristics in previous generations. The extent of homozygosity, not precisely known in the current generation may differ from each other in the degree of PRSV-W resistance, parthenocarpy and fruit/plant traits. 'Caserta' and 'Clarice' were open pollinated non-parthenocarpic PRSV-W susceptible cultivars, currently available on the market.

Diallel analysis was done according to Gardner and Eberhart (1966), adapted for partial diallel crosses by Miranda-Filho and Geraldi (1984).

Table 1 - Genetic material used in diallel crosses.

\begin{tabular}{ll}
\hline Lines & Code \\
\hline Group I & \\
$1=$ ABX-037G-77-03-05-01-01-bulk & $01-01$ \\
$2=$ ABX-037G-77-03-05-03-10-bulk & $03-10$ \\
$3=$ ABX-037G-77-03-05-01-04-bulk & $01-04$ \\
$4=$ ABX-037G-77-03-05-05-01-bulk & $05-01$ \\
\hline Group II & \\
1'=ABX-037G-77-03-05-04-08-bulk & $04-08$ \\
2'=ABX-037G-77-03-05-02-11-bulk & $02-11$ \\
3' = Clarice & Clarice \\
4'= Caserta & Caserta \\
\hline
\end{tabular}

\section{Parthenocarpy evaluation}

Seeds were sown in 128-cell styrofoam trays, filled with a commercial substrate (Plantmax $\left.{ }^{\circledR}\right)$. Seedlings were transplanted to beds (spacing $1.00 \mathrm{~m} \times 0.50 \mathrm{~m}$ ) when reaching the stage of two fully expanded true leaves. The 16 resultant hybrids, together with their eight parental lines, were evaluated in a randomized complete-block design, with three replications of ten plant-plots.

The evaluations were performed in individual plants. Female flowers were marked with red-wool string and protected with paper bags, one day before anthesis to so avoid insect pollination. Three female flowers per plant were bagged and scored separately. All already-opened flowers were removed, to so avoid fruit-set and competition from open-pollinated fruits. Fruit-development was scored fourteen days after bag-protection. A scoring system of 1 to 5 was used, as follows: $1=$ either fruit-length $<9 \mathrm{~cm}$, or fruit-base weak and/or with tissue necrosis; 2 = fruit length $9-11 \mathrm{~cm} ; 3=$ fruit length $11-13 \mathrm{~cm} ; 4=$ fruit length $13-15 \mathrm{~cm}$, and $5=$ fruit length $>15 \mathrm{~cm}$. Plant-scores were calculated as averages of the values of three flowers per plant. Plot-scores were the means of individual plant-scores within the plots. In this scale, fruits with full parthenocarpic development received a score of 5, and flowers aborted through not being pollinated, a score of 1 .

\section{Evaluation of yield-related traits}

The same trial used for evaluating parthenocarpy was repeated for assessing yield-related traits. Although there were three replications in most treatments, in some there were only two, through the lack of seeds. Adjusted means were first mutually compared by Dunnett-Hsu testing at 5\% probability, and then with the check cultivars (Clarice and Caserta). Statistical analysis was with SAS software (SAS Institute, 1990), whereby the following characters were evaluated: total fruit-yield (t.ha $\left.{ }^{-1}\right)$; fruit-weight (g.fruit ${ }^{-1}$ ); number of fruits per plant and early fruit-yield (t.ha ${ }^{-1}$ ). There were three harvests per week, 14 all told. Early-yield was the sum of the yields of the first three.

\section{Evaluation of PRSV-W resistance}

A separate trial was carried out in a plastic house for evaluation of PRSV-W reaction. Seeds were sown in trays filled with commercial substrate (Plantmax $\left.{ }^{\circledR}\right)$. Seedlings, on reaching the two true-leaf stage, were then transplanted into $3.4 \mathrm{~L}$ pots. The 16 resultant hybrids, together with their eight parents, were evaluated in a randomized complete block design, with two replications, seven plants per plot.

A PRSV-W isolate was stored at $-80^{\circ} \mathrm{C}$, for posterior confined (plastic house) multiplication C. pepo cv. Asmara, immediately preceding the trial. Purity of the viral inoculum was defined through mechanical inoculation into the following indicator host plants: C. pepo, Luffa acutangula, Chenopodium amaranticolor, Chenopodium quinoa, Gomphrena globosa, Nicotiana tabacum cv. Turk- 
ish NN and Nicotiana benthamiana. The inoculum itself was prepared by mortar-and-pestle grinding of PRSV-W infected leaves in a $0.01 \mathrm{M}$ phosphate buffer, $\mathrm{pH} 7.0$, plus $0.1 \%$ sodium sulfite. The buffer-to-leaf ratio was $9: 1(9 \mathrm{~mL}$ of buffer to $1 \mathrm{~g}$ of infected leaf). Two inoculations were carried out, the first in nine-day-old seedlings, and the second twelve days after the first. Mechanical inoculation was by first lightly dusting the cotyledonary leaves with 400-mesh carborundum, and then rubbing in the inoculum with the forefinger. After inoculation, the carborundum was rinsed off with water.

Five evaluations of viral symptoms were done, starting 10 days after the second inoculation, and subsequently at seven day intervals. Plants were scored individually for their reaction to PRSV-W, and rated with a scale from 1 to 5, as follows:

\section{$1=$ no visible symptoms.}

2 = most leaves without symptoms; one or a few leaves with mild symptoms, mostly vein clearing;

$3=$ most leaves with mosaic; symptoms varying from vein clearing with sparse chlorotic spots, to chlorosis in up to $50 \%$ of the leaf area;

4 = almost all the leaves with systemic mosaic coalescence of chlorotic areas, this reaching up to $50 \%$ of the total leaf area;

$5=$ almost all the leaves with severe mosaic; at least one leaf with more than $50 \%$ of its areas either affected or severely distorted.

Treatment means were compared with Duncan's multiple-range test at a $5 \%$ probability level. Heterosis and combining abilities were estimated according to Miranda-Filho and Geraldi (1984).

\section{Results and Discussion}

\section{Parthenocarpy evaluation}

Analysis of variance for parthenocarpy detected significant differences among treatments (Table 2). Diallel analysis revealed significant varietal effects within group II, thereby indicating that divergent additive effects within this group are important for parthenocarpic fruit-set. The heterosis effects were only significant for average heterosis, thereby indicating that hybrids deviated from the parental means for this trait. Estimates of heterosis related to parental means (Table 3) varied from -8,3\% (05-01 x Caserta) to $87,3 \%(01-01 \times$ Clarice $)$ - a wide variation, in which positive values predominated, a reflection of the reported dominance of the allele controlling parthenocarpic fruit-set (Menezes et al., 2005; Silva et al., 2009).

General combining ability (GCA) estimates $\left(g_{i}, g_{j}\right)$ varied within group I from -0.21 to 0.113 , an amplitude of 0.323 , quite small when compared to the mean $(\mu=2.255)$. On the other hand, $\mathrm{g}_{\mathrm{j}}$ 's within group II varied from -0.521 to 0.662 , a much larger amplitude (1.183), relative to the grand mean (Table 4). These values reflected the impor- tance of additive effects in group II, since this group included two cultivars (Caserta and Clarice) with near null parthenocarpic ability, in contrast with two other lines

Table 2 - Analysis of variance for parthenocarpy and reaction to PRSV-W in summer squash (C. pepo).

\begin{tabular}{lccc}
\hline \multirow{2}{*}{ Source of variation } & \multicolumn{3}{c}{ Mean squares } \\
\cline { 2 - 4 } & DF & Parthenocarpy & PRSV-W \\
\hline Treatments & 23 & $1.1289^{* *}$ & $1.7011^{* *}$ \\
Group I vs. Group II & 1 & $1.3924^{* *}$ & $3.6672^{* *}$ \\
Group I $\left(v_{i}\right)$ & 3 & $0.0699^{\mathrm{ns}}$ & $0.5066^{* *}$ \\
Group II $\left(v_{j}\right)$ & 3 & $6.5351^{* *}$ & $9.4710^{* *}$ \\
Heterosis & 16 & $0.2973^{*}$ & $0.3453^{* *}$ \\
Average heterosis & 1 & $1.8928^{* *}$ & $0.9165^{* *}$ \\
Heterosis for group I $\left(h_{i}\right)$ & 3 & $0.2521^{\mathrm{ns}}$ & $0.4643^{* *}$ \\
Heterosis for group II $\left(h_{j}\right)$ & 3 & $0.2929^{\mathrm{ns}}$ & $0.3020^{*}$ \\
Specific heterosis $\left(s_{i j}\right)$ & 9 & $0.1366^{\mathrm{ns}}$ & $0.2567^{* *}$ \\
Error & 23 & 0.1053 & 0.0685 \\
Means & & 2.53 & 3.40 \\
C.V \% & & 12.82 & 7.69 \\
\hline
\end{tabular}

ns, ${ }^{* *},{ }^{*}$, : nonsignificant and significant at 0.05 and 0.01 levels of probability, respectively.

Table 3 - Estimates of average heterosis (relative to midparent) for parthenocarpy and reaction to PRSV-W in summer squash hybrids.

\begin{tabular}{|c|c|c|c|c|}
\hline \multirow[t]{3}{*}{ Hybrids } & \multicolumn{4}{|c|}{ Average heterosis } \\
\hline & \multicolumn{2}{|c|}{ Parthenocarpy } & \multicolumn{2}{|c|}{ PRSV-W } \\
\hline & Value & $\%$ & Value & $\%$ \\
\hline $1 \times 1{ }^{\prime}$ & 0.455 & 14.8 & 0.090 & 3.5 \\
\hline $1 \times 2$ & 0.735 & 33.5 & 0.250 & 9.6 \\
\hline $1 \times 3{ }^{\prime}$ & 1.235 & 87.3 & 0.035 & 0.9 \\
\hline $1 \times 4^{\prime}$ & 0.335 & 19.5 & 0.255 & 6.5 \\
\hline $2 \times 1$, & 0.295 & 9.3 & 1.170 & 47.2 \\
\hline $2 \times 2^{\prime}$ & 0.475 & 20.8 & 0.540 & 21.3 \\
\hline $2 \times 3^{\prime}$ & 0.635 & 42.2 & 0.115 & 3.0 \\
\hline $2 \times 4^{\prime}$ & 0.525 & 29.1 & 0.975 & 25.6 \\
\hline $3 \times 1$ & -0.195 & -5.9 & 0.370 & 14.9 \\
\hline $3 \times 2$ & 1.015 & 41.5 & -0.250 & -9.8 \\
\hline $3 \times 3$, & 0.445 & 26.7 & -0.475 & -12.2 \\
\hline $3 \times 4^{\prime}$ & 0.445 & 22.6 & -0.035 & -0.9 \\
\hline $4 \times 11^{\prime}$ & -0.125 & -3.7 & 0.555 & 21.4 \\
\hline $4 \times 2{ }^{\prime}$ & 0.255 & 10.3 & -0.425 & -16.1 \\
\hline $4 \times 3^{\prime}$ & 0.375 & 22.1 & 0.650 & 16.5 \\
\hline $4 \times 4^{\prime}$ & -0.165 & -8.3 & 0.860 & 21.9 \\
\hline Std. Error & 0.281 & & 0.227 & \\
\hline
\end{tabular}

Treatments: 1 = ABX-037G-77-03-05-01-01-bulk, 2 = ABX-037G-7703-05-03-10-bulk, 3 = ABX-037G-77-03-05-01-04-bulk, $4=$ ABX037G-77-03-05-05-01-bulk, $1^{\prime}=$ ABX-037G-77-03-05-04-08-bulk, $2^{\prime}=$ ABX-037G-77-03-05-02-11-bulk, 3' = Clarice, 4' = Caserta. 
(04-08 and 02-11) obtained from crosses that included the Whitaker parthenocarpic cultivar. Contrary to CGA effects, specific combining ability (SCA) effects $\left(\mathrm{S}_{\mathrm{ij}}\right)$, which represent specific heterosis, varied from -0.309 to 0.389 , with an amplitude of 0.698 , thus showing the relative importance of non-additive effects, although on a lesser magnitude than those of additive. The higher magnitude of additive effects relative to non-additive can be observed in the estimates of additive [a] and non-additive [d] mean components.

GCA effects for parthenocarpic ability were positive for lines 1 (01-01) and 3 (01-04) within group I, and for lines 1' (04-08) and 2' (02-11) within group II, thereby indicating their favorable contribution to this the trait.

The largest SCA $\left(\mathrm{S}_{\mathrm{ij}}\right)$ effects were those of the combinations 1 x 3' and 3 x 2' (Table 4). The 1 x 3' hybrid displayed much greater parthenocarpic ability than expected from parental GCA's, which was negative in parental line 3'. The best hybrid combination usually combines the largest $S_{i j}$ with high $g_{i} / g_{j}$ values. Accordingly, the best parthenocarpic combination was $3 \times 2$ ' [= F1(01-04 x 02-11)], followed by $1 \times 1$ ' [= F1(01-01 x 04-08)], $2 \times 1$ ' [= $\mathrm{F} 1(03-10 \times 04-08)], 4 \times 1$ ' [=F1(05-01 x 04-08)] and $3 \times 1$ '

Table 4 - Estimates of the variety mean $(m)$, effects of varieties $\left(v_{i}\right.$ and $\left.v_{j}\right)$, variety heterosis $\left(h_{i}\right.$ and $\left.h_{j}\right)$, and general combining ability $\left(g_{i}\right.$ and $\left.g_{j}\right)$, and specific heterosis $\left(\mathrm{S}_{\mathrm{ij}}\right)$ for parthenocarpy and PRSV-W, according to the Gardner and Eberhart' (1966) model of diallel analysis.

\begin{tabular}{|c|c|c|c|c|c|c|}
\hline & \multicolumn{3}{|c|}{ Parthenocarpy } & \multicolumn{3}{|c|}{ PRSV-W } \\
\hline$[\mathrm{m}]$ & \multicolumn{3}{|c|}{$2.225 \pm 0.081$} & \multicolumn{3}{|c|}{$3.211 \pm 0.065$} \\
\hline [a] & \multicolumn{3}{|c|}{$0.421 \pm 0.099$} & \multicolumn{3}{|c|}{$0.293 \pm 0.080$} \\
\hline [d] & \multicolumn{3}{|c|}{$-0.295 \pm 0.081$} & \multicolumn{3}{|c|}{$-0.478 \pm 0.065$} \\
\hline Lines of the group I & $\mathrm{v}_{\mathrm{i}}$ & $\mathrm{h}_{\mathrm{i}}$ & $\left(g_{i}=1 / 2 v_{i}+h_{i}\right)$ & $\mathrm{v}_{\mathrm{i}}$ & $\mathrm{h}_{\mathrm{i}}$ & $\left(g_{i}=1 / 2 v_{i}+h_{i}\right)$ \\
\hline 1 & -0.310 & 0.268 & 0.113 & 0.057 & -0.135 & -0.106 \\
\hline 2 & -0.130 & 0.061 & -0.004 & -0.102 & 0.406 & 0.355 \\
\hline 3 & 0.190 & 0.006 & 0.101 & -0.082 & -0.388 & -0.429 \\
\hline 4 & 0.250 & -0.336 & -0.211 & 0.127 & 0.116 & 0.179 \\
\hline Std.error & 0.198 & 0.140 & & 0.160 & 0.113 & \\
\hline Lines of the group II & $\mathrm{v}_{\mathrm{j}}$ & $\mathrm{h}_{\mathrm{j}}$ & $\left(g_{j}=1 / 2 v_{j}+h_{j}\right)$ & $\mathrm{v}_{\mathrm{j}}$ & $\mathrm{h}_{\mathrm{j}}$ & $\left(g_{j}=1 / 2 v_{j}+h_{j}\right)$ \\
\hline 1 , & 1.950 & -0.313 & 0.662 & -1.360 & 0.253 & -0.427 \\
\hline 2 & 0.190 & 0.198 & 0.293 & -1.260 & -0.264 & -0.894 \\
\hline 3, & -1.370 & 0.251 & -0.434 & 1.310 & -0.209 & 0.446 \\
\hline 4, & -0.770 & -0.136 & -0.521 & 1.310 & 0.220 & 0.875 \\
\hline Std.error & 0.198 & 0.140 & & 0.160 & 0.113 & \\
\hline Hybrids & & $\mathrm{S}_{\mathrm{ij}}$ & & & $\mathrm{S}_{\mathrm{ij}}$ & \\
\hline $1 \times 1$ & & 0.079 & & & -0.321 & \\
\hline $1 \times 2$ & & -0.154 & & & 0.357 & \\
\hline $1 \times 3$, & & 0.294 & & & 0.087 & \\
\hline $1 \times 4$, & & -0.219 & & & -0.123 & \\
\hline $2 \times 1$ & & 0.126 & & & 0.217 & \\
\hline $2 \times 2$ & & -0.206 & & & 0.104 & \\
\hline $2 \times 3^{\prime}$ & & -0.099 & & & -0.376 & \\
\hline $2 \times 4$ & & 0.179 & & & 0.054 & \\
\hline $3 \times 1{ }^{\prime}$ & & -0.309 & & & 0.212 & \\
\hline $3 \times 2$ & & 0.389 & & & 0.109 & \\
\hline $3 \times 3^{\prime}$ & & -0.234 & & & -0.161 & \\
\hline $3 \times 4$ & & 0.154 & & & -0.161 & \\
\hline $4 \times 1$ & & 0.104 & & & -0.108 & \\
\hline $4 \times 2$ & & -0.029 & & & -0.571 & \\
\hline $4 \times 3{ }^{\prime}$ & & 0.039 & & & 0.449 & \\
\hline $4 \times 4$ & & -0.114 & & & 0.229 & \\
\hline Std.error & & 0.172 & & & 0.139 & \\
\hline
\end{tabular}

$[\mathrm{m}]=$ mid-parental value; $[\mathrm{a}]=$ additive genetic effects; $[\mathrm{d}]=$ non-additive genetic effects. Lines: $1=\mathrm{ABX}-037 \mathrm{G}-77-03-05-01-01-$ bulk, $2=\mathrm{ABX}-$ 037G-77-03-05-03-10-bulk, 3 = ABX-037G-77-03-05-01-04-bulk, 4 = ABX-037G-77-03-05-05-01-bulk, 1' = ABX-037G-77-03-05-04-08-bulk, 2' = ABX-037G-77-03-05-02-11-bulk, 3' = Clarice, 4' = Caserta. 
[ $=\mathrm{F} 1(01-04 \times 04-08)]$ (Tables 4 and 5). All these superior parthenocarpic combinations imply line $1^{\prime}=(04-08)$, the most expressive, to be the parent, with an average rate of 4.5 , near to the top of the scale (5). Obviously, this line can be considered homozygous for the allele that, according to Menezes et al. (2005), controls parthenocarpic expression in summer squash.

\section{Evaluation of the reaction to PRSV-W}

Through analysis of variance for reaction to PRSV$\mathrm{W}$, significant differences among treatments were detected (Table 2). Diallel analysis revealed significant varietal effects within groups I $\left(\mathrm{v}_{\mathrm{i}}\right)$ and II $\left(\mathrm{v}_{\mathrm{j}}\right)$, as well as the significant effects of average $(\mathrm{h}), \operatorname{varietal}\left(\mathrm{h}_{\mathrm{i}}, \mathrm{h}_{\mathrm{j}}\right)$ and specific $\left(\mathrm{s}_{\mathrm{ij}}\right)$ heterosis. Mean components indicated the greater influence of non-additive [d] than additive [a] effects, probably due to the importance of specific heterosis (Table 4).

Although heterosis as regards parental means, varied from $-16.1 \%$ to $47.2 \%$ for most of the hybrids, values were positive, i.e, towards higher susceptibility to PRSV-W (Table 3). Since resistance to PRSV-W is reportedly oligo or polygenic (Menezes CB, Doctoral thesis, Universidade Federal de Lavras, 2003), positive heterosis values can indicate that the alleles that control higher resistance to the virus (smaller scores) are predominantly recessive (Oliveira et al., 2003).

Estimates of GCA $\left(g_{i}, g_{j}\right)$ varied from -0.429 to 0.355 (amplitude of 0.784) for the lines of group I, and from -0.894 to 0.875 (amplitude of 1.77) for those of group II (Table 4). As regards parental means, the amplitude for additive effects (GCA) for the lines of groups I and II represented 24.41 and $55.12 \%$, respectively, thereby indicating that the lines of group II are more divergent from each other than those of group I.

The non-additive effects $\left(\mathrm{s}_{\mathrm{ij}}\right)$ varied from -0.571 to 0.449 (total amplitude of 1.02 , a value representing $31.7 \%$ of the grand mean). These results show that the nonadditive effects also contributed in an important way to the expression of PRSV-W resistance.

The effects of GCA on reaction to PRSV-W were negative for parental lines 1 and 3 in group I, and lines 1' and 2' in group II, thereby indicating their favorable genetic contribution towards resistance to the disease. On the contrary, lines 1' and 2' contrasted clearly with lines 3' ('Clarice') and 4' ('Caserta'), whose positive values for $\mathrm{v}_{\mathrm{j}}$ are an indication of their known susceptibility.

The best estimates of GCA were observed in lines 1 and 3 of group I, and lines 1' and 2' of group II, with values of $-0.106,-0.429,-0.427$ and -0.894 respectively (Table 4 ). The highest negative effects for SCA $\left(\mathrm{s}_{\mathrm{ij}}\right)$ were presented by the combination $4 \times 2$ ' and $2 \times 3$ ' (Table 4). Based on the GCA values of their parental lines, which were positive in lines 2 and 4 of group I, and in line 3' of group II, these hybrids proved to be much better than expected.
Scores for reaction to PRSV-W varied from 5.00 to 2.21 (Table 5). Scores of around 1.0 (= no symptoms) can be considered ideal, whereas those below 3 can be an indication of tolerance. The hybrid $4 \times 2$ ' was the most tolerant, with an average score of 2.21, thus differing statistically from most of the others. At least one parental line of this hybrid (2') presented a negative score for additive effects $\left(\mathrm{g}_{\mathrm{j}}\right)$, besides an association with negative estimates for nonadditive effects $\left(\mathrm{s}_{42}\right)$, thereby indicating that not only additive effects are important in the expression of this character. Besides the hybrid 4 x 2', others, such as $3 \times 2$ ' (score 2.29) and $1 \times 1$ ' (score 2.65) (Table 5), also presented satisfactory levels of tolerance to PRSV-W.

\section{Evaluation of fruit yield and yield-related traits}

Total yields all the hybrids were higher than for cultivar Clarice (20.6 t.ha $\left.{ }^{-1}\right)$, although only 1 x $4^{\prime}\left(38.9\right.$ t.ha $\left.{ }^{-1}\right)$

Table 5 - Average scores for parthenocarpy and reaction to PRSV-W for parents and hybrids of summer squash.

\begin{tabular}{|c|c|c|}
\hline Identification of treatments & Parthenocarpy & PRSV-W \\
\hline 1 & $1.65 \mathrm{HI}$ & 2.78 FGHI \\
\hline 2 & $1.82 \mathrm{HI}$ & $2.63 \mathrm{GHI}$ \\
\hline 3 & $2.15 \mathrm{GH}$ & $2.64 \mathrm{GHI}$ \\
\hline 4 & $2.20 \mathrm{FGH}$ & $2.86 \mathrm{FGH}$ \\
\hline 1 ' & $4.50 \mathrm{~A}$ & $2.32 \mathrm{HI}$ \\
\hline 2 ' & 2.7 CDEFG & $2.42 \mathrm{HI}$ \\
\hline $3^{\prime}$ & $1.17 \mathrm{I}$ & $5.00 \mathrm{~A}$ \\
\hline $4^{\prime}$ & $1.78 \mathrm{HI}$ & $5.00 \mathrm{~A}$ \\
\hline $1 \times 1{ }^{\prime}$ & $3.52 \mathrm{~B}$ & $2.64 \mathrm{GHI}$ \\
\hline $1 \times 2$ & $2.93 \mathrm{BCDEF}$ & $2.85 \mathrm{FGH}$ \\
\hline $1 \times 3^{\prime}$ & 2.64 DEFG & $3.93 \mathrm{CD}$ \\
\hline $1 \times 4^{\prime}$ & $2.05 \mathrm{GH}$ & $4.14 \mathrm{BC}$ \\
\hline $2 \times 1$ & $3.46 \mathrm{BC}$ & $3.64 \mathrm{CDE}$ \\
\hline $2 \times 2$ & 2.76 CDEFG & $3.07 \mathrm{EFG}$ \\
\hline $2 \times 3^{\prime}$ & $2.14 \mathrm{HG}$ & $3.92 \mathrm{CD}$ \\
\hline $2 \times 4^{\prime}$ & $2.32 \mathrm{FGH}$ & $4.78 \mathrm{~A}$ \\
\hline $3 \times 1$ & 3.12 $\mathrm{BCDE}$ & $2.85 \mathrm{FGH}$ \\
\hline $3 \times 2$ & $3.46 \mathrm{BC}$ & $2.29 \mathrm{HI}$ \\
\hline $3 \times 3$ & $2.11 \mathrm{GH}$ & 3.36 DEF \\
\hline $3 \times 4$ & $2.41 \mathrm{EFGH}$ & $3.78 \mathrm{CD}$ \\
\hline $4 \times 1$ & $3.23 \mathrm{BCD}$ & $3.14 \mathrm{EFG}$ \\
\hline $4 \times 2^{\prime}$ & $2.73 \mathrm{CDEFG}$ & $2.21 \mathrm{I}$ \\
\hline $4 \times 3^{\prime}$ & $2.07 \mathrm{GH}$ & $4.57 \mathrm{AB}$ \\
\hline $4 \times 4$ & $1.82 \mathrm{HI}$ & $4.78 \mathrm{~A}$ \\
\hline General average & 2.534 & 3.403 \\
\hline
\end{tabular}

No mutual differences in those means followed by the same letter were indicated by the Duncan test at $5 \%$ probability. Lines: $1=\mathrm{ABX}-037 \mathrm{G}-$ 77-03-05-01-01-bulk, 2 = ABX-037G-77-03-05-03-10-bulk, $3=$ ABX037G-77-03-05-01-04-bulk, $4=$ ABX-037G-77-03-05-05-01-bulk, $1^{\prime}=$ ABX-037G-77-03-05-04-08-bulk, 2' = ABX-037G-77-03-05-0211-bulk, 3' $=$ Clarice, $4^{\prime}=$ Caserta. 
and $4 \times 4^{\prime}$ ( 38.7 t.ha $\left.^{-1}\right)$ significantly so. Neither of the two differed from cultivar Caserta (45.5 t.ha ${ }^{-1}$ ) (Table 6). Most presented yields that ranged between those of 'Clarice' and 'Caserta'. On the other hand, all the parental lines presented significantly lower yields than cv. Caserta. The superior performance of hybrids in reference to parental lines (except 'Caserta') indicated heterosis for yield in summer squash.

All the ABX-037G lines presented fruit-weights similar to that of cv. Caserta (269 g.fruit $\left.{ }^{-1}\right)$, and greater (except for line 2) than that of cv. Clarice (115 g.fruit $\left.{ }^{-1}\right)$ (Table 6). Although ten out of the 16 hybrids presented mean fruitweights higher that of cv. Clarice, there was no difference from cv. Caserta. The mean fruit-weights of all the hybrids either approximated that of the best commercial cultivar ('Caserta') or, at least, ranged between 'Clarice' and 'Caserta'.
Although the amount of fruits harvested per plant varied among genotypes, none differed from either Caserta (8.46 fruits. plant $\left.{ }^{-1}\right)$ or Clarice (8.61 fruits. plant $\left.{ }^{-1}\right)$, probably due to the high coefficient of variation found for this trait (37.2\%) (Table 7). Early-yields in 'Caserta' were significantly higher (21.4 t.ha $\left.{ }^{-1}\right)$ than 'Clarice' $\left(10.7\right.$ t.ha $\left.^{-1}\right)$. Although all the other parental lines presented yields within these two limits, in lines 2 and 4, this was significantly lower than 'Caserta'. Twelve out of the 16 hybrids also presented early-yields varying between those of 'Clarice' and 'Caserta', but in only five ( $1 \times 2$ ', 2 × 1', $3 \times 1$ ', 4 × 1' and 4 $x 2^{\prime}$ ') was this significantly lower than 'Caserta'. On the other hand, in three hybrids ( $1 \times 3$ ', 2 x 4' and $3 \times 4^{\prime}$ ') early-yields were very similar to that of 'Caserta', and significantly higher than that of 'Clarice'.

In few hybrids with high levels of parthenocarpic expression and resistance to PRSV-W, was agronomic perfor-

Table 6 - Comparisons of the means in total yield and fruit-weight for 24 genotypes of summer-squash.

\begin{tabular}{|c|c|c|c|c|c|c|c|c|}
\hline \multirow[b]{2}{*}{ Treatments } & \multicolumn{4}{|c|}{ Total yield (t/ha) } & \multicolumn{4}{|c|}{ Fruit-weight (g/fruit) } \\
\hline & Means & Prob $>$ Clarice & Prob $>$ Caserta & Prob $<$ Caserta & Means & Prob $>$ Clarice & Prob $>$ Caserta & Prob $<$ Caserta \\
\hline 1 & 25.9 & ns & ns & $* *$ & 268 & $* *$ & ns & ns \\
\hline 2 & 21.2 & ns & ns & $* *$ & 220 & ns & ns & ns \\
\hline 3 & 23.6 & ns & ns & $* *$ & 280 & $* *$ & ns & ns \\
\hline 4 & 19.2 & ns & ns & $* *$ & 272 & $* *$ & ns & ns \\
\hline $1^{\prime}$ & 24.0 & ns & ns & $* *$ & 245 & $*$ & ns & ns \\
\hline $2^{\prime}$ & 20.0 & ns & ns & $* *$ & 269 & $* *$ & ns & ns \\
\hline $3^{\prime}$ & 20.6 & - & ns & $* *$ & 115 & - & ns & $*$ \\
\hline $4^{\prime}$ & 45.5 & $* *$ & - & - & 269 & $* *$ & - & - \\
\hline $1 \times 1^{\prime}$ & 32.2 & ns & ns & ns & 218 & ns & ns & ns \\
\hline $1 \times 2{ }^{\prime}$ & 17.6 & ns & ns & $* *$ & 183 & ns & ns & ns \\
\hline $1 \times 3^{\prime}$ & 37.4 & ns & ns & ns & 277 & $* *$ & ns & ns \\
\hline $1 \times 4^{\prime}$ & 38.9 & $*$ & ns & ns & 262 & $*$ & ns & ns \\
\hline $2 \times 1$ & 21.6 & ns & ns & $* *$ & 186 & ns & ns & ns \\
\hline $2 \times 2$ & 24.7 & ns & ns & $* *$ & 210 & ns & ns & ns \\
\hline $2 \times 3$ & 35.4 & ns & ns & ns & 269 & $* *$ & ns & ns \\
\hline $2 \times 4$ & 35.8 & ns & ns & ns & 215 & ns & ns & ns \\
\hline $3 \times 1$ & 20.3 & ns & ns & $* *$ & 169 & ns & ns & ns \\
\hline $3 \times 2$ & 22.6 & ns & ns & $* *$ & 242 & * & ns & ns \\
\hline $3 \times 3^{\prime}$ & 32.3 & ns & ns & ns & 255 & * & ns & ns \\
\hline $3 \times 4$ & 36.4 & ns & ns & ns & 269 & $* *$ & ns & ns \\
\hline $4 \times 1^{\prime}$ & 23.3 & ns & ns & $* *$ & 260 & * & ns & ns \\
\hline $4 \times 2{ }^{\prime}$ & 17.3 & ns & ns & $* *$ & 236 & $*$ & ns & ns \\
\hline $4 \times 3^{\prime}$ & 32.3 & ns & ns & ns & 264 & $* *$ & ns & ns \\
\hline $4 \times 4^{\prime}$ & 38.7 & $*$ & ns & ns & 264 & $* *$ & ns & ns \\
\hline General mean & 28.8 & & & & 251.0 & & & \\
\hline C.V $(\%)$ & 20.8 & & & & 15.4 & & & \\
\hline
\end{tabular}

ns $,{ }^{* *},{ }^{*}$, : nonsignificant and significant at 0.05 and 0.01 level of probability, respectively. Lines: $1=\mathrm{ABX}-037 \mathrm{G}-77-03-05-01-01-b u l k, 2=\mathrm{ABX}-$ 037G-77-03-05-03-10-bulk, 3 = ABX-037G-77-03-05-01-04-bulk, 4 = ABX-037G-77-03-05-05-01-bulk, 1' = ABX-037G-77-03-05-04-08-bulk, $2^{\prime}=$ ABX-037G-77-03-05-02-11-bulk, 3' = Clarice, 4' = Caserta 
mance also satisfactory. Only $1 \times 1$ ' outstanding in parthenocarpy and resistance to PRSV-W (Table 5), with yields and fruit-weight none the different from those of the highest yielding cultivar Caserta (Tables 6 and 7). If, in the absence of either virus-stress conditions or pollination deficiency, such as were the prevalent conditions in the trial of agronomic traits, this hybrid proved to be potentially competitive with 'Caserta', when undergoing virus stress or pollination deficiency, it's performance would presumably be superior.

In this trial, except for hybrid $1 \times 1$ ', no other hybrids with satisfactory parthenocarpic expression, resistance to PRSV-W, and yield could be identified. Although parthenocarpic expression in other hybrids derived from line 1' $\left(2 \times 1\right.$ ', $3 \times 1$ ' and $\left.4 \times 1^{\prime}\right)$ was satisfactory (Table 5), their yields were not (Table 6 and 7). On the other hand, even though in hybrids with either 'Clarice' or 'Caserta' as par- ents, yields were good (Table 6), resistance to PRSV-W was among the worst.

In conclusion, we could show that (1) even though both additive and non-additive effects were important in the expression of parthenocarpy and resistance to PRSV$\mathrm{W}$, non-additive effects were of higher importance for the latter trait than for the former; (2) one parental line (Line $\left.1^{\prime}=04-08\right)$ can be considered homozygotic for the allele that controls parthenocarpy; (3) the parental lines 'Clarice' and 'Caserta', by contributing negatively to PRSV-W resistance in their hybrids, enhanced their susceptibility; (4) although heterosis, as regards parthenocarpy, tended to improved parthenocarpic expression, for resistance to PRSV-W, the trend was towards higher susceptibility; (5) at least one hybrid [ 1 x 1' = F1 (01-01 x 04-08)] presented a combination of pronounced parthenocarpic expression, tol-

Table 7 - Comparisons of means in the number of fruits per plant and early-yield in 24 genotypes of summer squash.

\begin{tabular}{|c|c|c|c|c|c|c|c|c|}
\hline \multirow[b]{2}{*}{ Treatments } & \multicolumn{4}{|c|}{ Number of fruits/plant } & \multicolumn{4}{|c|}{ Early yield (t/ha) } \\
\hline & Means & Prob $>$ Clarice & Prob $>$ Caserta & Prob $<$ Caserta & Means & Prob $>$ Clarice & Prob $>$ Caserta & Prob $<$ Caserta \\
\hline 1 & 4.83 & ns & ns & ns & 17.2 & ns & ns & ns \\
\hline 2 & 5.20 & ns & ns & ns & 12.3 & ns & ns & $*$ \\
\hline 3 & 4.22 & ns & ns & ns & 16.0 & ns & ns & ns \\
\hline 4 & 3.61 & ns & ns & ns & 12.9 & ns & ns & $* *$ \\
\hline 1 ' & 5.02 & ns & ns & ns & 14.8 & ns & ns & ns \\
\hline 2 ' & 3.58 & ns & ns & ns & 15.4 & ns & ns & ns \\
\hline 3 , & 8.61 & - & ns & ns & 10.7 & - & ns & * \\
\hline 4 ' & 8.46 & ns & - & - & 21.4 & $*$ & - & - \\
\hline $1 \times 1$ & 9.40 & ns & ns & ns & 15.9 & ns & ns & ns \\
\hline $1 \times 2$ & 5.19 & ns & ns & ns & 9.4 & ns & ns & * \\
\hline $1 \times 3$ & 6.77 & ns & ns & ns & 22.5 & $*$ & ns & ns \\
\hline $1 \times 4$ & 7.44 & ns & ns & ns & 19.4 & ns & ns & ns \\
\hline $2 \times 1$ & 6.38 & ns & ns & ns & 12.9 & ns & ns & $*$ \\
\hline $2 \times 2$ & 6.38 & ns & ns & ns & 14.3 & ns & ns & ns \\
\hline $2 \times 3^{\prime}$ & 6.56 & ns & ns & ns & 18.5 & ns & ns & ns \\
\hline $2 \times 4^{\prime}$ & 8.65 & ns & ns & ns & 20.5 & $*$ & ns & ns \\
\hline $3 \times 1$ & 6.54 & ns & ns & ns & 10.3 & ns & ns & $* *$ \\
\hline $3 \times 2$ & 4.89 & ns & ns & ns & 13.4 & ns & ns & ns \\
\hline $3 \times 3$ & 6.45 & ns & ns & ns & 18.8 & ns & ns & ns \\
\hline $3 \times 4$ & 6.75 & ns & ns & ns & 20.2 & $*$ & ns & ns \\
\hline $4 \times 1$ & 4.49 & ns & ns & ns & 12.0 & ns & ns & $* *$ \\
\hline $4 \times 2$ & 3.94 & ns & ns & ns & 9.7 & ns & ns & $* *$ \\
\hline $4 \times 3$ & 6.20 & ns & ns & ns & 17.0 & ns & ns & ns \\
\hline $4 \times 4^{\prime}$ & 7.27 & ns & ns & ns & 19.6 & ns & ns & ns \\
\hline General means & 5.95 & & & & 16.4 & & & \\
\hline C.V(\%) & 37.26 & & & & 19.0 & & & \\
\hline
\end{tabular}

ns ${ }^{* *},{ }^{*}$, : non-significant and significant at 0.05 and 0.01 level of probability, respectively. Lines: $1=\mathrm{ABX}-037 \mathrm{G}-77-03-05-01-01-\mathrm{bulk}, 2=\mathrm{ABX}-$ 037G-77-03-05-03-10-bulk, 3 = ABX-037G-77-03-05-01-04-bulk, 4 = ABX-037G-77-03-05-05-01-bulk, 1' = ABX-037G-77-03-05-04-08-bulk, 2' = ABX-037G-77-03-05-02-11-bulk, 3' = Clarice, 4' = Caserta. 
erance to PRSV-W, and satisfactory yield and mean-fruit weight.

\section{Acknowledgments}

The authors wish to acknowledge the agencies and companies in Brazil that supported this research project: FAPEMIG (Fundação de Amparo à Pesquisa de Minas Gerais), CNPq/MCT (Conselho Nacional de Desenvolvimento Científico e Tecnológico), CAPES/MEC (Coordenação de Aperfeiçoamento de Pessoal de Nível Superior), UFLA (Universidade Federal de Lavras), FAEPE (Fundação de Apoio ao Ensino, Pesquisa e Extensão), and HortiAgro Sementes Ltda.

\section{References}

Ahmed EA, Ibn Oaf HS and El Jack AE (2003) Combining ability and heterosis in line $\mathrm{x}$ tester crosses of summer squash (cucurbita pepo 1.). Cucurbit Genet Coop Report 26:54-56.

Firpo IT, López-Anido F, Garcia SM and Cointry E (1998) Heterosis in summer squash (Cucurbita pepo L.). Cucurbit Genet Coop Report 21:43-45.

Gardner CO and Eberhart SA (1966) Analysis and interpretation of the variety cross diallel and related populations. Biometrics 22:439-452.

López-Anido F, Firpo IT, Garcia SM and Cointry E (1998) Combining ability in summer squash (Cucurbita pepo L.). Cucurbit Genet Coop Report 21:40-42.
Maluf WR, Moura WM, Silva IS and Castelo-Branco M (1986) Screening of Cucurbita spp. accessions for resistance to Watermelon MosaicVirus-1. Braz J Genet 9:161-167.

Menezes CB, Maluf WR, Azevedo SM, Faria MV, Nascimento IR, Nogueira DW, Gomes LAA and Bearzoti E (2005) Inheritance of parthenocarpy in summer squash (Cucurbita pepo L.). Genet Mol Res 4:39-46.

Miranda-Filho JB and Geraldi IO (1984) An adapted model for the analysis of partial diallel crosses. Braz J Genet 7:677688.

Oliveira ACB, Maluf WR, Pinto JEBP and Azevedo SM (2003) Resistance to papaya ringspot virus in summer squash Cucurbita pepo L. introgressed from an interspecific $C$. pepo x C. moschata cross. Euphytica 132:211-215.

Provvidenti R, Robinson RW and Munger M (1978) Resistance in feral species to six viruses infecting cucurbita. Plant Disease Report 62:326-329.

Robinson RW and Reiners S (1999) Parthenocarpy in Summer squash. Hort Sci 34:715-717.

SAS Institute (1990) SAS/STAT User's Guide. SAS Institute, Cary, N.C.

Silva MIS, Bearzoti E and Bueno-Filho JSS (2009) Bayesian analisys of monogenic inheritance model in plant breeding: A case study with zucchini. Ciênc Agrotecnol 33:14631468.

Associate Editor: Adriana S. Hemerly

License information: This is an open-access article distributed under the terms of the Creative Commons Attribution License, which permits unrestricted use, distribution, and reproduction in any medium, provided the original work is properly cited. 